УДК 7.071.072.3:[070.489:792](477)"197/198"(045)

ORCID ID: 0000-0003-3776-4103

Бубнова Вікторія Вікторівна, аспірантка кафедри театрознавства. Київський національний університет театру, кіно і телебачення імені I. К. Карпенка-Карого, Київ

Бубнова Виктория Викторовна, аспирантка кафедры театроведения. Киевский национальный университет театра, кино и телевидения имени И. К. Карпенка-Карого, Киев

Viktoriia Bubnova,

Postgaduate Student of the Theater Studies Department. Kyiv National I. K. Karpenko-Karyi Theatre, Cinema and Television University, Kyiv

\title{
ТВОРЧИЙ ПОРТРЕТ МИТЦЯ: АВТОРИ, ТИПОЛОГІЯ, ГЕРОЇ (За матеріалами журналу «Український театр» 1970-1980-х років)
}

Анотація. У статті зроблено аналіз особливостей жанру театральної критики — творчого портрета митця у період 1970-80-х рр. Аналіз спирається на публікації у центральному професійному театральному виданні - журналі «Український театр». Визначені основні автори, герої, запропонована типологія: історичний портрет, ювілейний портрет, портрет в одній ролі, портрет-інтерв'ю, портрет-особисте ставлення, портрет-відгук, колективний портрет.

Ключові слова: жанри театральної критики, творчий портрет, театрознавство, театральна критика, український театр.

Постановка проблеми та ї̈ актуальність. За останні тридцять років система підготовки театрознавців у закладах вищої освіти України майже не змінювалась - вона базується на тих самих принципах і долає ті самі проблеми, що були визначені ще у 1980-х роках і з часом тільки загострювались. Практика театральної критики 1970-80-х років, тісно пов'язана з вимогами радянського суспільства і тогочасною ідеологією, не $є$ достатньо вивченою і потребує осмислення. Важливими для вивчення є жанри театральної критики, що переважали на сторінках періодичної преси, серед яких один з найпоказовіших — творчий портрет.

Розглядаючи матеріали у жанрі творчого портрета, видрукувані на сторінках журналу «Український театр», виникає необхідність відповісти на такі питання:

Яку частку від загального обсягу театрально-критичних матеріалів становив творчий портрет і чи можливо передбачити, як це було врегульовано редакцією журналу?
Хто найчастіше писав творчі портрети - театрознавці, мистецтвознавці, інші митці?

Хто саме потрапляв у поле зору театральної критики - актори, режисери, представники інших театральних професій і цехів?

Чи можна окреслити типологію творчого портрета за означений період?

Які творчі портрети вирізняються нетиповим стилем подачі та оригінальністю задуму?

Чи можливо визначити, за якою схемою був побудований творчий портрет митця?

Mema cmammi. Проаналізувати, як був представлений жанр творчого портрета на сторінках журналу «Український театр» - провідного фахового видання України - упродовж 1970-1980х років, окреслити типологію творчого портрета, визначити основних авторів, виявити особливості стилю написання матеріалів у цьому жанрі.

Аналіз останніх досліджень $і$ публікацій. Проблема жанрів української театральної критики другої половини XX століття є маловивченою. Мистецтвознавці здебільшого звертаються у сво- 
ïх працях до періоду XIX - першої половини XX ст. - О. Клековкін, Ю. Полякова, В. Собіянський, А. Коржова, М. Гарбузюк, а період 197080 років лишається майже не висвітленим.

Питання методології, основні принципи аналізу явищ театральної культури піднімає у своїх працях О. Клековкін. У статті «Портрет митця: предмет дослідження у жанровому пограниччі», що написана на матеріалі текстів П. Руліна, присвячених аналізу творчості М. Заньковецької, він відзначає, що

$<\ldots>$ літературний (творчий) портрет, недостатньо чітко артикульовано, що й вимагає уточнень предмета театрознавства і театральної журналістики - кола питань, на які намагається отримати відповіді театрознавство, а які залишає критиці. (Клековкін, 2019, с. 9)

А у навчальному посібнику «Театрознавство: Предметне поле» автор, спираючись на публікації П. Руліна, М. Вороного, В. Хмурого, Вс. Чаговця, В. Василька та інших, розглядає саме жанрові особливості літературного (творчого) портрета, пропонує різні шляхи до визначення предмета дослідження під час його написання та розробляє умовну типологію - академічний портрет, популярний, ідеологічний, белетристично-«поетичний» і методологічний (Клековкін, 2019, с.114). Автор аналізує жанр творчого портрета 3 точки зору театрознавства. А творчі портрети, надруковані у журналі «Український театр» у 1970-80-х роках, є театрально-критичними публікаціями, орієнтованими на вимоги часу (від ідеологічних змін у країні до орієнтації на пресу «швидкого реагування» - тексти до певних дат, ювілеїв, прем'єр, газетні формати), тож за цією типологією усі їх можна було б умовно віднести тільки до такого типу, як «популярний аналіз».

Театральну критику 1970-х років досліджував В. Неволов. У дисертації він концентрується на таких питаннях: хто $є$ авторами публікацій у періодичній пресі, чому рецензії несвоєчасні, чому наявна тематична вибірковість до одних і тих самих колективів. Говорячи про жанри, В. Неволов зауважує:

українська театральна критика $<\ldots>$ не завжди також користується різноманітними жанровими можливостями. Основним жанром (34\%) була стандартна рецензія, <..>, 12 \% складали проблемні статті, 17\% — творчі портрети. (Неволов, 1988, c.15)

Для уточнення вимог, які висувалися до творчого портрета у театральній критиці, звернімося до навчальних посібників 1970-80 років. $\mathrm{y}$ «Методичних вказівках до виконання семінарських робіт з театральної критики», що були затверджені Управлінням кадрів і навчальних закладів Міністерства культури СРСР у 1969 році, заплановано дві праці, що являють собою по суті творчий портрет. На 3 курсі у I семестрі - «роботу про одного актора у 2-3-х ролях, що дозволяє узагальнити найхарактерніші риси його творчості, визначити особливості акторської індивідуальності» (Хайченко, 1969, с. 7) обсягом 8-10 сторінок - така робота мала б стати містком до написання згодом аналізу вистави. А на 4 курсі передбачався «Творчий портрет сучасного радянського актора, режисера, драматурга, критика, театрального художника» обсягом до 1 авторського аркуша (24 сторінки).

Вказівки містять лише узагальнені рекомендації: праця має містити огляд творчого шляху діяча, написаний на основі вивчення матеріалів статей, рецензій, архівів, інтерв'ю 3 митцем та 3 його оточенням, а в основній частині - власні спостереження, спроби виявлення особливостей творчого стилю.

У «Методичних вказівках до програми семінару “Театральна критика" для театрознавчих факультетів театральних вузів», виданих у 1978 році, написання творчого портрета передбачається лише на третьому році навчання. Рекомендації подібні, тільки підсилені цитатами 3 праць К. С. Станіславського та посиланнями на програму КПРС.

«Методичні вказівки до семінару “Театральна критика" для театральних інститутів зі спеціальності №2217 “Театрознавство”» 1986 року — найзмістовніші й містять конкретніші поради: як аналізувати роботу актора і режисера, як обрати митця для своєї роботи. Але в жодному з підрозділів не вказано такий жанр, як «творчий портрет», лише — «аналіз роботи актора», «аналіз роботи режисера».

До проблем театральної критики звертались також у своїх статтях провідні театрознавці та театральні критики окресленого періоду Ю. Бобошко, С. Васильєв, С. Веселка, В. Заболотна, Н. Срмакова, Р. Коломієць, В. Неволов, Л. Новоселицька, А. Поляков, Л. Приходько, М. Соколянський, і практики театрального мистецтва (О. Барсегян, В. Добровольський, О. Кусенко, Є. Пономаренко, Д. Чайковський). Автори зазначають, що критика описова, не вміє аналізувати акторські роботи:

саме актор стає тим рубежем, на якому закінчується потік красномовності і рецензенти друж- 
но переходять на стиль лаконічний, трохи не телеграфний: “оригінально вирішено”, “вдало передає”, “правильно намічено”, “яскраво окреслені”, “помітна удача", “колоритна постать”, “економічно і вражаюче”. (Приходько, 1970, с. 25)

Час від часу у статтях піднімають і питання жанрів театральної критики (А. Поляков, В. Неволов), а щодо творчих портретів, то зазначають, що цей жанр є одним 3 найпоширеніших у пресі, але «Тут критика чи не найбільше схильна до компліментарності» (Поляков, 1984, с. 5), що «єлейні “ювілейно-портретно-монографічні” статті дедалі впертіше тіснять статті проблемні, оглядові...» (Неволов, 1985, с. 14), що «віддається перевага “оціночній” методі. Причому хорошими вважаються позитивний відгук і той критик, який його висловив» (Срмакова, 1986, с. 4).

Виклад основного матеріалу. У січні 1969 року було оприлюднено Постанову секретаріату ЦК КПРС «Про підвищення відповідальності керівників органів друку, радіо, телебачення, кінематографіiі, установ культури і мистецтва за ідейно-політичний рівень матеріалів, що публікуються, та репертуару». Це було пов'язано з процесами, які відбувались у державі: після певних свобод для митців у 50-60-х роках (Фестивалі молоді і студентів у Москві, читання віршів молодих поетів біля пам'ятників Пушкіну і Маяковському, поява на сцені нової радянської драматургії (i навіть зарубіжних п'єс), відкриття літературних журналів, вихід у прокат кінострічок, що піднімали досі замовчувані проблеми радянського суспільства тощо), починається поступовий процес «закручування гайок». Це можна простежити за низкою публікацій у пресі, згаданих, приміром, у монографії В. Фіалка: «У пресі друкувалися статті, де говорилося про втрату театром свого обличчя, найкращих традицій» (Фіалко, 2016, c. 51). Тож цілком послідовним видається Наказ голови комітету по пресі при Раді Міністрів Української РСР, датований 10 квітня 1969 року, про те, що у відповідності з постановою директивних органів з січня 1970 року на базі журналу «Мистецтво» і додатка до нього «Новини кіноекрана» видаватимуться чотири самостійних видання, одне 3 яких - журнал «Український театр», що журнал є органом Міністерства культури УРСР і Українського театрального товариства. У наказі також врегульовано, що датою заснування журналу треба вважати 1936 рік. Наказ підписано Головою Комітету по пресі при Раді Міністрів УРСР М. Білогуровим [ЦДАМЛМ України. Фонд 980, опис 1 , справа 1, с.1].
Цілі та завдання журналу «Український театр» було висловлено у №1 1970 року у статті I. Чабаненка «Роздуми про майбутнє журналу»:

Звичайно, журналу “Український театр” доведеться одразу братися, і не абияк, за розгляд того, що робиться, і навіть що має робитися в театрах. Не байдужим він має бути і до закладів, де формуються театральні кадри. Чимало на нього чекає $\mathrm{i}$ таких справ, що їх порушують наші театрознавці, висуває саме життя. (Чабаненко, 1970, с. 9)

У протоколі №1 від 19 березня 1970 року [ЦДАМЛМ України. Фонд 980, опис 1, справа 604, с.1] зазначалося, що роботу журналу мають скеровувати чотири відділи - відділ Теорії театру, Історії театру, Критики та Інформації, конкурсів, народних театрів, керівниками яких було призначено Ю. Богдашевського, О. Сулименка, Л. Приходько і О. Гончаренко відповідно.

Які основні жанри функціонували на сторінках журналу? Це творчий портрет, проблемна стаття, рецензія, огляд, фейлетон.

У 1970-х роках кількість статей за жанрами розподілялась так: за цей період було надруковано у спеціальних рубриках «Творчі портрети» - 107, «Проблема» (проблемні статті) - 132 , «Рецензії, огляди» - 190. У 1980-х роках «Творчі портрети» - 128, «Проблеми» (проблемні статті) - 120, «Огляди, рецензії» - 132.

Помітно, що значно скоротилась кількість рецензій та збільшилась кількість творчих портретів. Чому виникають такі розходження? Тому що у період 1980-х років, особливо після 1986 року, журнал значно розширює свою рубрикацію. Так, якщо з 1970 до 1986 року рубрик було від 10 до 15, то з 1987 року їх кількість збільшується іноді до 37. (О. Клековкін, який активно співпрацював 3 журналом у цей період, пояснює збільшення числа рубрик тим, що іноді вони з'являлись під одну конкретну статтю - щоб матеріал був правильно сприйнятий читачем, спеціальна рубрика уточнювала проблему.)

Але розмаїття рубрик не означало розмаїття жанрів. Певна кількість статей була надрукована не в звичних рубриках «Портрети» (або «Штрихи до портрета» - у 80-х рр.), «Огляди, рецензії», «Проблеми», а, наприклад, у таких, як «Актуальна тема», «Полемічні нотатки», «Про наболіле», «Наш співрозмовник», «Нові театри, нові імена», «Дебют» тощо. Тому підрахунок є дещо узагальненим.

У перші ж роки роботи журналу на засіданнях редколегій піднімалось і питання жанрового розмаїття. Вже у протоколі №1 засідання редколегії 
журналу від 19 березня 1970 року Ю. Станішевський говорив про те, що в №1 журналу «Український театр» «<..> вміщено велику кількість творчих портретів. Зменшивши їх кількість, можливо буде збільшити кількість рецензій» [ЦДАМЛМ України. Фонд 980, опис 1, справа 604. с.1]. Переглянувши перелік матеріалів перших двох номерів, бачимо, що видрукувано 4 портрети митців театру, i 14 портретів акторів у ролі Леніна - у 1970 році святкувався 100-річний ювілей Леніна, що було декларовано і у вступних статтях цих номерів, таким чином, з 28 матеріалів у №1 та №2 - більше половини становили портрети.

Майже чверть усіх театрально-критичних публікацій у журналі «Український театр» за період 1970-1990 pp. - це матеріали у жанрі творчого портрета.

У 1970-1979 рр. рубрика «Портрет» налічує 107 матеріалів. 3 них понад $70-$ портрет актоpa, 8 - режисерів, 6 - театральних художників та 2 - театральних фотохудожників, 3 - драматургів, 2 - колективних портрети, присвячені нещодавно організованим театрам, по 1-му - про театрального композитора, театрознавця та директора театру.

У 1980-1990 рр. рубрика «Портрет» містить 128 матеріалів: більш ніж 70 - портрет актора, 17 - режисерів, 12 - художників, 6 - драматургів, 3 статті про педагогів театральних вишів, 2 - колективних портрети, по 1-му - про театрознавця, директора театру, художника зі світла, освітлювача, композитора, диригента, фотохудожника тощо.

Хоча у 1980-ті роки збільшується кількість статей про представників різних театральних професій, але за 20 років - це лише третина від загальної кількості творчих портретів.

Найчастіше у жанрі творчого портрета в означений період писали такі автори: Л. Багінська, Ю. Богдашевський, С. Веселка, В. Гайдабура, В. Гуменюк, І. Давидова, В. Міліца, К. Пітоєва, С. Смілянська, А. Сулименко, С. Сулименко, О. Чепалов, В. Ясногородський; рідше - А. Драк, Р. Коломієць, Н. Медведєва, О. Мельник, Л. Філіпенко, М. Френкель, В. Судьїн.

Хто ж потрапляв у поле зору критиків, чию роботу вони намагались аналізувати у творчих портретах?

Більшу частину (70-75\%) становили портрети акторів. Зазвичай це були визнані майстри, заслужені та народні артисти УРСР і РРФСР (наприклад, у №1 журналу — заслужена артистка УРСР Леся Луценко, народний артист УРСР Ярослав
Геляс) і лише інколи - молоді виконавці. Це питання обговорювалось і на засіданні редколегії: у протоколі №2 від 13 липня 1971 року С. Сміян зауважив, що «хотів би бачити більше творчих портретів акторів, в тому числі молодих» [ЦДАМЛМ України. Фонд 980, опис 1, справа 605, с. 7].

Портрети акторів часто писали Л. Багінська, С. Веселка, В. Гуменюк, В. Міліца, В. Ясногородський, рідше - I. Давидова, О. Мельник, К. Пітоєва, С. Сулименко, Л. Філіпенко, О. Чепалов, В. Гайдабура.

Творчих портретів режисерів набагато менше. За цей період - по три статті належать С. Beселці, В. Гайдабурі, по дві статті - Ю. Богдашевському та О. Клековкіну, та по одному матеріалу видрукували Л. Приходько, С. Сулименко, Р. Коломієць, О. Ягодовська, Т. Моцар та ін.

Про кого з режисерів писали творчі портрети? Серед них як визнані майстри - О. Беляцький, В. Грипич, С. Данченко, В. Довбищенко, В. Оглоблін, Ф. Стригун, О. Утеганов, так і ті, кого Р. Коломієць назвав «"нова хвиля" української режисури» (Коломієць, 1988, с. 20): І. Афанасьєв, Я. Маланчук, В. Малахов, М. Нестантінер, I. Равицький, В. Петров. Зазначимо, що майже усі портрети молодих режисерів з'явились після 1986 року. Також видрукувана низка портретів режисерів лялькового театру - В. Афанасьєва, О. Інюточкіна, С. Єфремова, Ю. Сікала, Б. Смирнова тощо.

Творчості художників-сценографів присвячені по три творчі портрети К. Пітоєвої (одна у співавторстві з Д. Лідером) та М. Френкеля, два С. Сулименка. Про художників на сторінках журналу по одній статті - у С. Веселки, В. Гайдабури, Г. Кононенка та ін.

Серед портретів художників-сценографів по два матеріали про Данила Лідера та Федора Hiрода, про учнів «школи Лідера»; окрему нішу займають художники театру ляльок - Р. Марголіна, А. Родіонова. Є матеріали про Л. Альшица, І. Биченкова, М. Іваницького, М. Кипріяна, М. Ковальчук, Т. Медвідь, В. Мелещенкова, В. Руденка (у 70-х рр.) та В. Геращенка, Г. Косарєва, Т. Медвідь, I. Шулика - у 80-х. Портрети молодих сценографів - учнів «школи Лідера» - В. Карашевського, С. Коштелянчука, С. Маслобойщикова - теж 3'являються після 1986 року.

Таким чином, налічується 20 авторів, які писали у жанрі творчого портрета, з яких 10 мали постійні публікації, а решта — час від часу. 3 цих авторів театрознавцями за освітою були не всі. Лариса Багінська, Юрій Богдашевський, Віктор Гу- 
менюк, Аркадій Драк, Кіра Пітоєва отримали театрознавчу освіту у Київському інституті театрального мистецтва, Олександр Чепалов - у ЛДІТМіКу, Валерій Гайдабура та Неллі Медведєва-Шейко закінчили філологічні факультети, Ірина Давидова - педагогічний 3ВО, Світлана Рябокобиленко (Веселка) - факультет журналістики у Львові. Сергій Сулименко теж був журналістом. Ростислав Коломієць закінчив режисерський курс Бориса Олійника в Київському театральному інституті, Володимир Ясногородський - режисуру у Ленінградському державному театральному інституті, Володимир Судьїн та Анатолій Сулименко теж режисери. Михайло Френкель - художник-сценограф, навчався у школі-студії МХАТ. Світлана Смілянська працювала завідувачкою літературної частини у Волинському театрі.

Під час вивчення матеріалів можна помітити, що за авторами закріплюється певна тематика або регіон. Ю. Бобошко - історичний портрет, Ю. Богдашевський - масштабні портрети, присвячені режисерові В. Данченку і портрети молодих акторів; С. Веселка частіше пише про театр на Заході УРСР (Львів, Івано-Франківськ, Ужгород); В. Гайдабура - про театри Запоріжжя i Дніпропетровська, про Запорізький театр імені М. Щорса; В. Гуменюк - про акторів театрів Житомирщини; К. Пітоєва та М. Френкель — про творчість художників-сценографів; С. Смілянська - про майстрів Волинського театру ляльок, a В. Ясногородський - про акторів Севастопольського театру імені А. Луначарського.

У авторів помітний власний стиль — і у вибоpi героя, і у прийомах написання портрета.

Наприклад, портрети, написані С. Веселкою, мають такі характерні риси: авторка згадує, з яких ролей починав актор, навіть якщо це ролі другорядні; в яких ролях зміг найбільше розкритись, які вистави стали візитівкою актора і за що саме його полюбив глядач. йдеться про режисерів, то С. Веселка звертає увагу на складні аспекти творчого шляху і кар'єри - конфліктні ситуації у колективі, пошук творчих тандемів та формування команди «своїх» акторів.

Світлана Веселка одразу називає ім'я героя статті, робить узагальнений аналіз професійної майстерності, підсилюючи його реконструкцією сцен $з$ вистави, детальним описом мізансцени i дій актора у ролі:

Такий принцип побудови комедійного образу властивий акторові і в інших виставах <..> рідкісна органічність, чарівність крупної людської індивідуальності, чіткість думки, уміння миттєво встановлювати контакт з партнерами і глядачами роблять персонажів Аркадьєва надзвичайно вірогідними й людяними» <... >Аркадьєв може розхвилювати до сліз і розсмішити до такого ж стану. (Веселка, 1970, с. 6-7);

С. Олексенко не зрадив себе в цій ролі: він залишився приязним, комунікабельним, по-людськи симпатичним <..> Гармонійна цілісність індивідуальності Степана Олексенка... < ..> Гармонійна цілісність сприйняття світу — мабуть, так можна визначити природу чарівливості актора. (Веселка, 1982, с. 19)

Юрій Богдашевський $є$ автором творчих портретів режисера Сергія Данченка - стаття «У пошуках однодумців» у №1 1970 року та «Данченко» у №1 1987 року. Тут наявний біографічний принцип, коли згадується період навчання, початок кар'єри у Львівському ТЮГу імені М. Горького, несподіваний перехід до театру імені М. Заньковецької, пізніше - до театру імені I. Франка у Києві. Автор акцентує увагу на важливих професійних якостях режисера - як Данченко будував творчу команду, як обирав для постановки п’єси і чому після 1980-х років більше звертається до класичної драматургії, ніж до сучасних радянських п’єс, яким надавав перевагу на початку кар'єри. Також автор піднімає і гості теми - конфлікти 3 керівництвом, внутрішні протистояння між знаними акторами театру, які доводилось «гасити» режисерові, несприйняття режисера трупою театру та ін. У портретах, створених Ю. Богдашевським, сформульовані основні режисерські принципи Данченка, особливості роботи з художником, актором: «Він не режисер “показу”, який щохвилини вибігає на сцену, намагаючись зіграти за всіх. Він не режисер-диктатор, який хоче, щоб актор грав лише так, а не інакше. $<\ldots>$ Він вірить в актора» (Богдашевський, 1970, с. 19). Це - той випадок, коли творчий портрет змістовно і повно змальовує постать митця.

Героями творчих портретів Валерія Гайдабури були майстри Запорізького театру імені Щорса. У портреті актора К. Параконьєва, який приходить у режисуру в зрілому віці, автор зупиняється переважно на його акторському доробку — масштабні ролі, характерні риси, притаманні його героям. У портреті В. Магара, головного режисера театру імені М. Щорса, В. Гайдабура концентрується на творах, що їх обирав режисер для постановок, і пошуку особливостей його режисерського стилю. У портреті режисера В. Грипича автор вивчає його співпрацю $з$ художником і композитором, а також - який творчий напрям він розви- 
ває у театрі імені М. Щорса. Портрет художника В. Геращенка побудований за біографічним принципом - як майстер потрапив до театру, з якими режисерами співпрацював і в яких п'єсах якнайповніше, на думку автора статті, розкрився його талант сценографа.

Створюючи творчі портрети художників-сценографів, Кіра Пітоєва звертає увагу на такі питання: які творчі принципи сповідує художник, 3 чого починається його задум образу вистави. В iï статтях детально змальовані сценографічні образи найяскравіших вистав, є пояснення масштабності задуму, ставиться питання пошуку однодумця-режисера або «свого» театру.

Велика частина творчих портретів на сторінках журналу належить авторам, які друкувалися лише один-два рази - це завідувачі літературних частин театрів, режисери, актори. Приводом до написання матеріалу були - ювілей актора/режисера театру, в якому вони працювали, або необхідність ширшого представлення певного театру в журналі.

Помітно, що ці портрети написані за схожою схемою і мають характерні ознаки: часто у 2-3 перших абзацах ім'я героя портрета не називається - автор ніби тримає інтригу; використовується біографічний принцип - змальовано дитинство і юність митця, роки навчання, початок кар'єри в різних театрах; коротко (по одному абзацу) перелічуються усі значні ролі (або вистави, якщо йдеться про режисера чи сценографа) - 3 узагальненою характеристикою; рідше - автор зупиняється детальніше на двох-трьох значних роботах майстра.

Дехто з акторів і режисерів пише «від себе»описують своє знайомство 3 видатним майстром сцени, згадують уроки майстерності, які отримали у співтворчості з ним.

Такі портрети містять повну інформацію про заслуги і почесні нагороди майстра, перелік ролей (вистав), імена режисерів чи колег-акторів, 3 якими він співпрацював і в яких саме театральних колективах, як прийшов у професію. Але не аналізують творчість митця, не описують його творчий метод, принципи роботи над роллю/п'єсою і т.д.

Висновки. Кількість творчих портретів на сторінках журналу «Український театр» за період 1970-1990 рр. становила чверть від усіх публікацій.

- Типологія. Піджанри, на які розгалужувався творчий портрет, можна умовно позначити так:

- Iсторичний портрет.

- Ювілейний портрет - біографічний нарис до ювілею митця з аналізом провідних робіт (ролей, вистав, творів тощо).
- Портрет в одній ролі (в означений період значна кількість матеріалів аналізує, наприклад, чи «впорався/не впорався» визнаний артист 3 образом Леніна).

- Портрет-інтерв'ю - стаття, що містить вступне слово (підводку) - обсягом від одного абзацу до однісї сторінки — i бесіду 3 героєм статті, що переривається коментарями критика.

- Портрет-особисте ставлення - автор змальовує своє знайомство з митцем і його творчістю, спираючись на власні враження, аналізує творчий доробок митця.

- Портрет-відгук - наближається до есею, створений у довільній формі й теж містить особисте сприйняття автором статті роботи актора в ролі.

- Колективний портрет (такі матеріали друкувались у рубриці «Портрети», але розглядали діяльність молодого, недавно створеного, театрального колективу або народного театру; такий колектив мав ще недостатньо «заслуг» для окремих портретів у провідному фаховому виданні, але була потреба відзначити яскраві роботи певних виконавців).

Схема. Статті були побудовані за схожими принципами: біографія героя, його творчий шлях від навчання до перших ролей (постановок) у театрі, перелічені найяскравіші роботи, три-чотири 3 яких коротко або детально проаналізовані.

Основні автори. Основними авторами творчих портретів - за кількістю видрукуваних матеріалів - $\epsilon$ театрознавці, хоча у цьому жанрі часто писали режисери і актори. Бачимо, що за авторами закріплювалась певна тематика: за принципом географічним або за тематичним.

Герої. Героями портретів найчастіше є актори - визнані майстри сцени, які мали почесні звання і значний творчий доробок. Значно менше портретів присвячено режисерам і художникам-сценографам і по одному-два матеріали представникам інших театральних професій драматургам, композиторам, критикам, художникам зі світла тощо.

Серед творчих портретів, видрукуваних на сторінках журналу «Український театр» - поетичні нариси про акторів, святкові портрети до ювілеїв, почесних звань, нагород, портрети, що містили соціальну тематику тощо. Узагальнюючи, дійдемо висновку, що більшість з них не виконує свою головну функцію - вони не містять професійного аналізу роботи актора/режисера/художника і не відповідають на професійні питання: як 
саме народжується роль/вистава/образ вистави, яка технологія процесу творчості митця.

\section{Бібліографія}

Барбой, Ю.М., Иванова, В.В., Калмановский, Е.С., Лапкина, Г.А., Марченко, Т.А., Рябинянц, Н.А., (Сост.). (1986). Мeтодические указания к семинару «Театральная критика» для театральных институтов по специальности №2217 «Театроведение». Москва. ЛГИТМиК имени Н. К. Черкасова.

Богдашевський, Ю. (1987). Данченко. Украӥнський театр. 144 (1). С. 25-27.

Богдашевський, Ю. (1970). У пошуках однодумців. Український театр. 56 (1). С. 18-20.

Веселка, С. (1982). Таким він приходить до нас. Український meamp. 115 (2). С. 18-20.

Веселка, С. (1970). Щедрість. Украӥнський театр. 58 (3). C. 6-7.

Срмакова, Н. (1986). Критик і театр : діалог на користь мистецтву. Украӥнський театр. 143 (6). С. 3-5.

Клековкін, О.Ю. (2019). Портрет митця: предмет дослідження у жанровому пограниччі. Науковий вісник Київського національного університету театру, кіно ітелебачення імені. І. К. Карпенка-Карого. Вип. 25. С. 7-14.

Клековкін, О.Ю. (2019). Театрознавство: Предметне поле: Навчальний посібник. КНУТКіТ ім. І. К. Карпенка-Карого. Київ: Арт Економі. 128 с.

Коломієць, Р. (1988). Стійкий принц. Український театр. 153 (4). C. 20-23.

Неволов, В. (1985). Між театром і глядачем. Украӥнський театр. 132 (1). С. 14-15.

Неволов, В. (1988). Театральный процесс на Украине и критика семидесятых годов : автореф. дисс. ... канд. искусствоведения : 17.00.01 «Театральное искусство»/ Киев. гос. институт театрального искусства им. И. К. Карпенко-Карого. Москва.

Поляков, А. (1984). Турботи критичного цеху. Український театр. 130 (5). С. 4-6.

Приходько, Л. (1970). «Повнометражні звивини душі». Український театр. 46 (5). С. 25-27.

Фіалко, В.О. (2016). Театр Украӥни другої половини ХХ століття: образна лексика. Київ: Видавничий дім «Антиквар». $430 \mathrm{c}$.

Хайченко, Г.А. (Сост.). (1969). Методические указания к выполнению семинарских работ по театральной критике. Москва: ГИТИС имени А. В. Луначарского.

Чабаненко, I. (1970). Роздуми про майбутнє журналу. Украӥнський театр. 56 (1). С. 9-10.

Эльяш, Н.И. (Сост.). (1978). Методические указания к программе семинара «Театральна критика» для театроведческих факультетов театральных ВУЗов. Москва. ГИТИС имени А. В. Луначарского.

\section{References}

Barboj, YU.M., Ivanova V.V., Kalmanovskij, E.S., Lapkina, G.A., Marchenko, T.A., Ryabinyanc, N.A., (Ed.). (1986). Metodicheskie ukazaniya $k$ seminaru "Teatral'naya kritika» dlya teatral'nyh institutov po special'nosti №2217
"Teatrovedenie». [Methodical instructions for the seminar «Theatrical Criticism» for theatrical institutes in the specialty №2217 «Theatrical Studies»]. Moscow. LGITMiK. [in Russian]

Bohdashevskyi, Yu. (1987). Danchenko [Danchenko]. Ukrainskyi teatr. [Ukrainian theatre]. 144 (1), pp. 25-27. [in Ukrainian]

Bohdashevskyi, Yu. (1970). U poshukakh odnodumtsiv. [In search of like-minded people]. Ukrainskyi teatr. [Ukrainian theatre]. 56 (1), pp. 18-20. [in Ukrainian]

Veselka, S. (1982). Takym vin prykhodyt do nas. [This is how he comes to us]. Ukrainskyi teatr. [Ukrainian theatre]. 115 (2), pp. 18-20. [in Ukrainian]

Veselka, S. (1970). Shchedrist. [Generosity]. Ukrainskyi teatr. [Ukrainian theatre]. 58 (3), pp. 6-7. [in Ukrainian]

Yermakova, N. (1986). Krytyk i teatr: dialoh na koryst mystetstvu. [Critic and theatre: a dialogue in favor of art]. Ukrainskyi teatr. [Ukrainian theatre].143 (6), pp. 3-5. [in Ukrainian]

Klekovkin, O.Iu. (2019). Portret myttsia: predmet doslidzhennia $\mathrm{u}$ zhanrovomu pohranychchi. [Portrait of an artist: a subject of research in the genre frontier]. Naukovyi visnyk KNUTKiT im. I. K. Karpenka-Karoho. [Scientific Bulletin Kyiv National I. K. Karpenko-Karyi Theatre, Cinema and Television University. 25, pp. 7-14. [in Ukrainian]

Klekovkin, O.Iu. (2019). Teatroznavstvo: Predmetne pole: Navchalnyi posibnyk. [Theatre Studies: Subjects: Tutorial]. KNUTKiT imeni I. K. Karpenko-Karoho [Kyiv National I. K. Karpenko-Karyi Theatre, Cinema and Television University]. Kyiv: Art Economy. 128 s. [in Ukrainian]

Kolomiiets, R. (1988). Stiikyi prynts [The steadfast prince]. Ukrainskyi teatr. [Ukrainian theatre]. 153 (4), pp. 20-23. [in Ukrainian]

Nevolov, V. (1985). Mizh teatrom i hliadachem. [Between the theatre and the audience]. Ukrainskyi teatr. [Ukrainian theatre]. 132 (1), pp. 14-15. [in Ukrainian]

Nevolov, V. (1988). Teatral'nyj process na Ukraine $i$ kritika semidesyatyh godov [Theatrical process in Ukraine and criticism of the seventies]. (Extended abstract of candidate's thesis). Kyiv I. K. Karpenko-Karyi institute of theatrical art. Moscow. [in Russian]

Poliakov, A. (1984). Turboty krytychnoho tsekhu. [Worries of the criticism]. Ukrainskyi teatr. [Ukrainian theatre]. 130 (5), pp. 4-6. [in Ukrainian]

Prykhodko, L. (1970). «Povnometrazhni zvyvyny dushi». [«Fulllength twists of the soul»] Ukrainskyi teatr. [Ukrainian theatre]. 46 (5), pp. 25-27. [in Ukrainian]

Fialko, V.O. (2016). Teatr Ukrainy druhoi polovyny XX stolittia: obrazna leksyka. [Theatre of Ukraine of the second half of the twentieth century: figurative vocabulary]. Kyiv: Antikvar Publishing House. 430 s. [in Ukrainian]

Hajchenko, G.A. (Comp.). (1969). Metodicheskie ukazaniya $k$ vypolneniyu seminarskih rabot po teatral'noj kritike. [Methodical instructions for seminar work on theatre criticism]. Moscow: GITIS. [in Russian]

Chabanenko, I. (1970). Rozdumy pro maibutnie zhurnalu. [Reflections on the future of the magazine]. Ukrainskyi teatr. [Ukrainian theatre]. 56 (1), pp. 9-10. [in Ukrainian]

El'yash, N.I. (Comp.). (1978). Metodicheskie ukazaniya k programme seminara "Teatral'na kritika» dlya teatrovedcheskih fakul tetov teatral'nyh VUZov. [Methodical instructions to the program of the seminar «Theatrical Criticism» for theatrical faculties of theatrical universities]. Moscow: GITIS. [in Russian] 


\section{Viktoriia Bubnova}

Creative portrait of artist: authors, to the typology, heroes (There is the «Ukrainian theatre» of 1970-1989th on materials of magazine)

Abstract. The article analyzes the peculiarities of the genre of theater criticism - the creative portrait of the artist in the period 1970-80. the analysis is based on publications in the central professional theater publication - the magazine «Ukrainian theater». The main authors and characters are identified, and the typology is proposed: historical portrait, anniversary portrait, portrait in one role, portrait-interview, portraitpersonal attitude, portrait-review, collective portrait.

Keywords: genres of theater criticism, portrait of the artist, theater studies, theater criticism, Ukrainian theater.

\section{Бубнова Виктория Викторовна}

Творческий портрет художника: авторы, типология, герои

(По материалам журнала «Украинский театр» 1970-1989-х годов)

Аннотация. В статье сделан анализ особенностей жанра театральной критики - творческого портрета художника в период 1970-80-х гг. Анализ опирается на публикации в центральном профессиональном театральном издании - журнале «Украинский театр». Определены основные авторы, герои, предложена типология: исторический портрет, юбилейный портрет, портрет в одной роли, портрет-интервью, портрет-личное отношение, портрет-отзыв, коллективный портрет.

Ключевые слова: жанры театральной критики, творческий портрет, театроведение, театральная критика, украинский театр. 